This is an Accepted Manuscript of an article published by Taylor \& Francias in Critical Studies in Media Communication on 2017, available online:

https://www.tandfonline.com/doi/abs/10.1080/15295036.2017.1358820 


\title{
Television fiction and online communities. An analysis of comments on social networks and forums made by female viewers
}

Charo Lacalle and Núria Simelio

Faculty of Communication Sciences, Autonomous University of Barcelona (Barcelona), Spain

\begin{abstract}
This article analyses the feeling of communities of female social viewers who watch television fiction and participate in social networks and forums dedicated to the programmes. The sample is made up of 7,849 comments from 157 platforms (49 Facebook pages, 71 Twitter accounts and 37 forums). We describe the characteristics of these communities of fans, which differ significantly from cult fandoms and are based on ICT interweaving between reception and female viewers' daily lives. The results reveal that these active online poster and lurker communities express themselves through their emotional ties with the television series, self-reflection and the manifestation of intimacy. Identification with the group is based on the relationship of the storylines with their own lives, with no attempts at constructing a cultural or political identity.
\end{abstract}

\section{Key words}

Television, audiences, social media, internet, online communities, female identities

\section{Introduction}

Studies on the activity of television fiction fans on the internet have mainly focused on cult fandom and on very specific audience groups that manifest a great degree of involvement and expertise on the products on which they comment (Baym, 2000; Booth, 2008; Duffett, 2013; Bury, 2016). However, less expert fan communities, who react more spontaneously, though constantly, to consumed products, have often been overlooked despite the importance of the contributions in understanding the characteristics and behaviour of audiences in the current media ecosystem (Hills, 2010). This is of special importance in the 
case of female fans, who have been undervalued by academia (Salazar, 2015) or investigated only in relation to certain questions, such as subcultures (Jenkins, 1992), the creation of fanfiction and slash (Bury 2005), or teenage and young fans (Black, 2008).

This article explores the online activity of communities of fans of television programs in social television. The analysis sample is made up of 7,849 comments signed with feminine names (either names or nicknames) posted on the social networks and forums of 72 new fiction programmes produced by general Spanish networks (national and regional) and broadcast between 2012 and 2013. The study assumes as a starting point that the increasing popularity of television fiction and its alliance with the internet has generated new loyalties between viewers that diversify the traditional adhesion shown by fans of cult series. Multiscreen consumption and the modification of the structure of fandom are studied with the aim of describing the characteristics of a community of fans based on "ICT interweaving" between viewing and daily life (Bailliencourt et al., 2011, p. 152).

\section{The active online audience in the current media context}

The current media ecosystem, which is characterised by the proliferation of devices and the various different uses to which they are applied, immerses television consumers in a process of polymediation that has appreciably changed the daily lives of viewers and their relationship with the media. Accordingly, all users with access to the internet have simultaneously become "producers, audiences, and critics who can describe, react, examine and assess the implications of ongoing discourses and technological advances" (Herbig, Herrmann and Tyma, 2015, pág $\mathrm{xx})$.

The consequences of these new ways of consumption by audiences and fans are notable. As MacDowell and Zborowski state (2013,pág 3), “e-fan writing can dramatically alter the relationship between fans and their objects of adulation by allowing fans to be acknowledged as producers rather than mere passive recipients of cultural messages". However, despite the fact that the current media ecosystem is supposed to enable all users to become producers, the assertions of Jenkins (2006) and Bruns (2006) that a large part of the audience is becoming interactive, blurring the line between consumers and producers and revolutionizing the notion of audience, seem over optimistic. In fact, most users do not become producers, unless "we regard every twitter and Facebook update as an act of creativity" (Bird, 2011, p. 512).

In this context, television fiction viewers have become prolific users of social networks in which they interact and comment on contents on various multiscreen formats 
(Bury, 2016). The new ways of consuming have generated hybrid processes that enable spectators to combine the use of digital media (through Apps, social networks and forums) with watching television (Wood and Taylor, 2008,pág 145). As Herbig, Herrmann and Tyma (2015, p. xx) point out:

There is a relationship between the technological artifacts or tools (smartphone, laptops, etc.), the various sites of mediated communication (Facebook, Twitter, Snapchat, FaceTime, etc.), and the processes of communication, that help define our relationship with each.

Consequently, the process of audience involvement with the television product is diversifying and viewers' activity on digital media can no longer be reduced to the mere existence of two types of audience (one an active producer, the other passive) but of the genres and television formats themselves, the social circumstances and even the spectators' mood (Wilson, 2016, p. 187).

Our investigation begins by asking what an active audience means in this new communication framework. In line with Costello and Moore (2007, p. 138), we assume that any viewer who participates in an online activity related to television fiction is active in the sense that $\mathrm{s} / \mathrm{he}$ transcends his/her own act of watching television. We therefore consider that a community of fans does not only encompass spectators who produce contents or redefine the narrative interpretation, but also include all those users who participate to varying degrees in the social networks and forums dedicated to the programmes. Moreover, this participation enables each user to define his/her own identity by using different profiles, platforms and purposes to express themselves, manifesting their values and beliefs through all forms while exploring new possibilities and facets of the self. (Calka, 2015, p. 22).

The various possibilities of interaction, strengthened by ICTs, extend the sociability traditionally associated with television reception (Ling and Thrane, 2002) and raise the need to examine fan communities from the new perspective of the behaviour of online communities. In this regard, the concepts poster and lurker (Sun et al., 2014) are extremely useful in better profiling the participation space generated among admirers, fans and cult fans defined by Brooker and Brooker (1996, p. 141). Like fans, posters actively participate, contributing to creating a feeling of community that could encourage lurkers -generally passive users- to overcome their fear of taking part. 


\section{The change in fandom structure: other types of media practices}

The first studies on fans considered these specific subculture or counterculture collectives to be highly knowledgeable of the media product they consumed. First wave authors of studies on fandom (Hills, 2002; Jenkins, 1992), influenced by Certeau (1990), mainly described fans as a participative community that pioneered the use of new technologies to share and interact via the internet (Gray et al., 2007; Pearson, 2010). Gradually, the internet and the expansion of these communities led investigators to redefine them as practices that have widened and installed themselves into the everyday lives of the majority of people of all ages over much of their lifetime (Harrington et al., 2010).

Web 2.0 has prompted studies on fandom (Gray, 2005), even in questioning the definition of fan community itself (Jenkins, 2007) and, in some cases, even the future of fandom, which has been replaced by a new type of generazised active audience (Gray et al., 2007). However, what has really occurred is a transition towards another kind of fandom related not only to the expansion of mediatization and to economic, technological and cultural changes, but also to certain demographic transformations -with increasingly older audiences - that have had an impact on media industries throughout the world. (Harrington, 2011, p. 583).

In general terms, it could be said that digital communities which share opinions on fiction share characteristics common to earlier fan communities in terms of the construction of identity and the establishment of interpersonal relationships, which are reflected in the defense of the group itself and the sharing of their personal experiences (Baym, 2000). They also share other common transformative features, such as the tendency to maintain anonymity, to challenge social taboos, to defend sexual diversity, and to resist dominant ideologies and cultural norms (Brennan, 2014, p. 376), as well as more negative aspects, including initiation rituals, hierarchies, stereotypes and intra-group conflicts (Pearson, 2010, p. 93). In short, in a world of changing identities, "being a fan is an important means for the articulation and reaffirmation of individual identity positions" (Sandvoss, 2013, p. 286).

This is especially important in relation to women, who make up the majority of fans of mainstream television fiction, while the followers of cult fiction, which relate more to horror and violence, are in the main men (Cherry, 2002). The generalized disinterest, if not contempt, of the scientific community towards female fandom is reflected, for example, in the negative connotation of many terms related to the concept of fangirls (Salazar, 2015). Nevertheless, fandom has also allowed women to express their sexuality and emotions, to 
create groups based on their interests and to appropriate many storylines created from a male perspective despite the generalized tendency to consider their tastes as banal and to ridicule their expressions (Salazar, 2015, p. 90).

Similarly, the platform used is another indicator that can be used to differentiate cult fandoms from the type of fan communities to which we are referring. Booth (2008) and Bury (2005) consider that certain platforms such as MySpace and LiveJournal encourage a high level of commitment among fans, and become a focus of support for creativity and solidarity among communities. However, some of the most popular social pages, including Facebook or Twitter, do not foster deep interactivity due to their technical and functional limitations.

In summary, it could be said that investigations on digital fan communities have mainly focused on studying cult fandom -which involves a high degree of expertise and produces new contents- without taking into account more spontaneous fans. These fans, who follow and comment on different types of programmes while they are being broadcast, are extremely important in understanding the functioning of audiences and fan communities, which explains their cultural endurance alongside ordinary television:

Television studies may benefit from less work on highly visible 'event' and (mainstreamed) 'cult' television and their fans, which may appeal to publishers and the student population, and more on secluded 'momentary' fandom, often that of older audiences (Hills, 2010, p. 107).

In this regard, our study considers it necessary to explore the function of spontaneous fandom based on the interaction between individuals who share an interest in a particular cultural product, thereby allowing them to form part of a community in which they become involved at the personal level, but who cannot be defined simply as consumers alone. (Salazar, p. 78). As Bielby and Harrington (1995) note, they can carry out activities associated with fans without being fans, and vice versa, since fanship is not defined solely through activity, but also through identity.

Hence the importance of studying the consumption practices of posters and lurkers increasingly more numerous- who lie equidistant between cult fans and anti-fans (Gray, 2005). These spectators passionately follow the fictions they like and interact in forums and social networks, although without becoming deeply involved in the product. Moreover, their actions are pragmatic in nature, being motivated by immediate objectives such as preventing the cancellation of a series or calling for a new season. 
Another aspect that should be considered is the importance and value the rest of the community attributes to other members' opinions, particularly in female groups, a reflection of a female ethic related to gift culture, which consists of reciprocally giving and receiving and an altruistic purpose (Hellekson, 2009). Consequently, all these factors contribute to construct a feeling of community between fans based on their mutual involvement, sharing a meeting "place", trusting each other, having emotional attachments, partaking in an exchange of social support, friendship, recreation and value of similar things (e.g. being fans of the same TV shows). (Ridings and Gefen, 2004).

In contrast to the historic image of the obsessive fans and geeks, the new audience is more mature and sophisticated, which inspires meaningful exchanges in online discussions. In this regard, it could be stated that the internet has empowered these fans as an alternative to the commercial television narratives (Costello and Moore, 2007), thus demonstrating that they are critical investigators and commentators rather than passive viewers (Duffett, 2013).

This study is structured around the two following questions:

Q.1.: In what way do domestic fiction communities created on the internet differ from traditional cult fandoms?

Q.2.: What type of actions do female social spectators carry out to create and maintain a feeling of community?

\section{Materials and methods}

The sample consists of 7,849 posts signed with feminine names (either names or nicknames), gathered from 157 sites (49 Facebook pages; 71 Twitter feeds and 37 forums) dedicated to the 72 shows that premiered between 2012 and 2013, at a ratio of 50 comments per platform. The selection of comments focused on the last episode, promoted by broadcasters as a media event (Williams 2015), which prompts an exponential increase in the number of comments (Larsen, 2010). Since spontaneous comments do not allow the gender of the users to be determined, this study assumed the construction of a feminine identity through language — corroborated by morphological agreements of the languages spoken in Spain $^{1}$ —. Pictures and avatars are also differentiating elements of the posts making up the sample. The need to carry out a manual selection was determined by the few guarantees of reliability provided by web crawler tools and data mining programs such as R programming language (Spottswood et al., 2013) in identifying the verbal cues employed by internet users to project their gender. The study assumes, therefore, that those commenting adopt a female 
public persona to interact with the internet community, regardless of whether or not they are biologically female.

The definitive version of the analysis code was implemented after an initial pilot study of the comments of 15 shows, carried out by 15 investigators who cover the four official Spanish languages (Spanish, Catalan, Basque and Galician) ${ }^{2}$. Once the classification of the comments (tagging) had been completed and the analysis units filtered by code, the interpretative process was initiated. The codebook $(\mathrm{N}=39)$ used as a guide for the descriptive analysis was divided into six sections: identification, storytelling, community, extimacy, social issues and other issues.

The analysis explores the feeling of community of users. We therefore focused on those comments that convey, either directly, indirectly or figuratively, a sense of belonging to a community of fans: storytelling (storylines, characters, actors/actresses); community (community, interaction, pragmatics); and extimacy (self-reflection, emoticons).

\section{Results}

The 7,849 messages making up the analysis sample generated 22,301 items ${ }^{3}$ that form a long tail (Anderson, 2006).

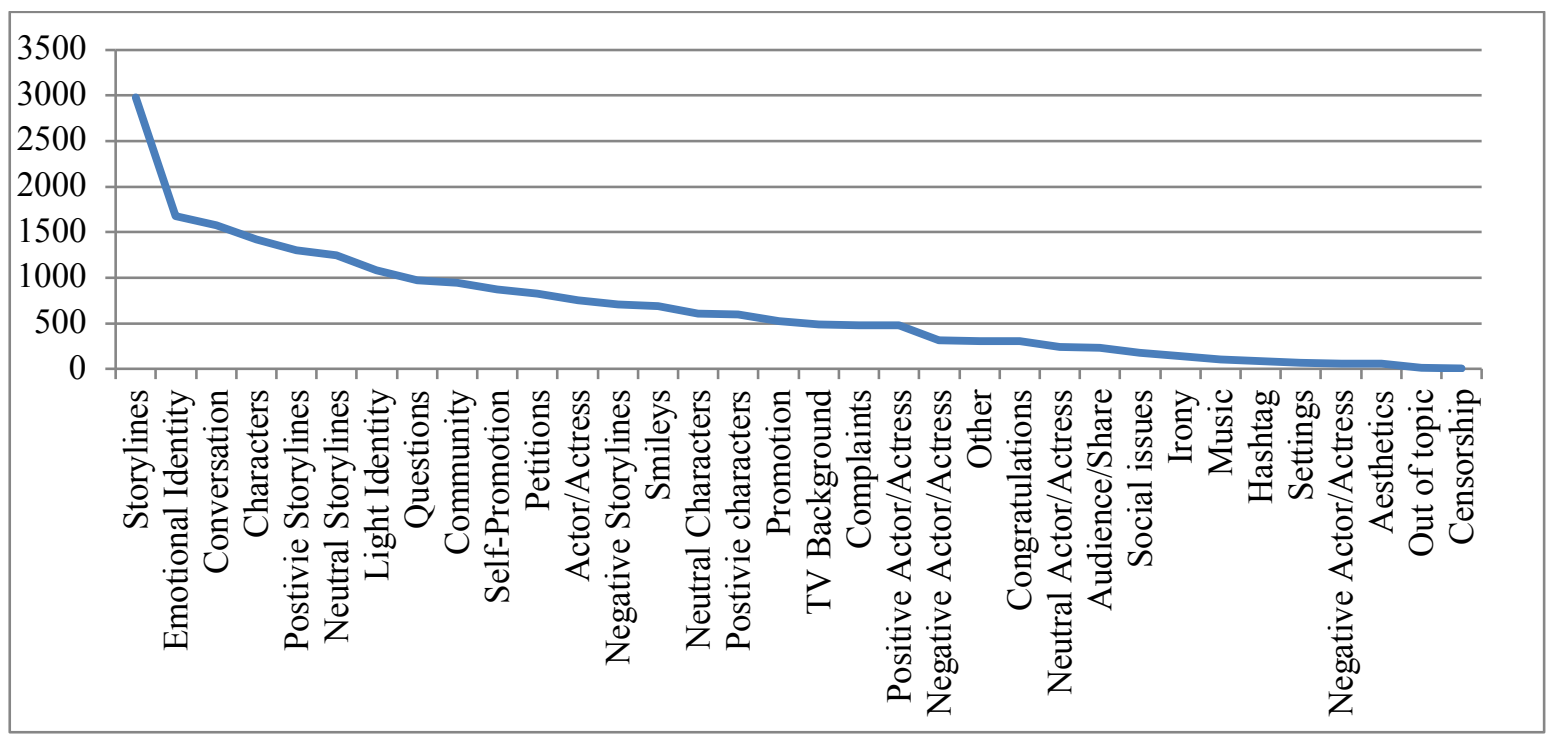

Figure 1. The long tail of the social public's discourses

The resulting figure takes the form of a "large head" which includes references to storylines and the emotional identity of female users, and a "long tail" made up of miscellaneous issues such as negative comments about actors/actresses and characters, complaints, the programme's soundtrack, the control of messages in the various websites, etc.

Figure 1. The long tail of the social public's discourses 


\section{Storytelling}

On the comments analysed, $57 \%(\mathrm{~N}=4,471)$ were about the programs' contents. The social audience's emotional connection with the storylines is generally positive $(\mathrm{N}=1,297$; $43.5 \%)$ or neutral $(\mathrm{N}=1,242 ; 41.67 \%)$, while the negative comments represent only $23.8 \%$ $(\mathrm{N}=709)$.

Female viewers mainly use Facebook to share their positive opinions, with 50.6\% $(\mathrm{N}=627)$ of the comments belonging to this group, in contrast to $28.4 \%(\mathrm{~N}=352)$ for Twitter and $18.0 \%$ (223) for forums. There are also more negative comments on Facebook (43.9\%; $\mathrm{N}=311)$ and forums (38.4\%; $\mathrm{N}=272)$ than Twitter $(11.6 \% ; \mathrm{N}=82)$. The more conversational nature of forums also has an influence on the weight of neutral opinions on these platforms $(52.9 \% ; \mathrm{N}=432)$ compared to Twitter $(25.61 \% ; \mathrm{N}=209)$ and Facebook $(15.4 \% ; \mathrm{N}=126)$.

Series set in the past generate the greatest number of positive comments and reveal the pleasure of reception. In general, criticisms mainly concern open endings or the sudden termination of series that did not reach expected audience figures. Inconsistencies and mistakes detected in some of the storylines also frequently fuel dialogue between users and occasionally strengthen the feeling of community:

Tita Pilu - 15/11/2012 - 21:25

Now that Amar has finished I'm going to miss the forum. I've met such lovely people who episode by episode have forged an everlasting friendship. We've been happy when the episodes were good, occasionally bored when the plots were tiring, angry with some of the errors that could have been avoided and we've criticised the scriptwriters but I think we'll miss all this now (...) (Amar en tiempos revueltos, La1, 20025-2012)4.

Of the 1.,422 comments about the characters, $42.0 \%(\mathrm{~N}=597)$ were positive, $22.0 \%$ $(\mathrm{N}=131)$ were negative and $42.9 \%(\mathrm{~N}=610)$ were neutral. Forums accounted for $36.2 \%$ $(\mathrm{N}=465)$ of this group's messages, followed by Twitter $(35.6 \%$; $\mathrm{N}=457)$ and Facebook, with $28.1 \%(\mathrm{~N}=361)$. The number of positive comments about male characters $(\mathrm{N}=303)$ was greater than female characters $(\mathrm{N}=212)^{5}$, although only 25 comments explicitly $\mathrm{d}$ to any physical aspect. In fact, the admired male characters were, respectively, a patriarch described by the female viewers as a "villain" (Vicente, Gran Reserva, La1, 2010-20136) and a sitcom anti-hero hailed for his "freakiness" (Luisma, Aida, Tele5, 2005-20147). The most acclaimed female characters are usually appreciated for their personality (Lola, Frágiles, Tele5, 2012$2013^{8}$ ) or their outlandishness (Estela, La que se avecina, Tele5, 2007-9 ). Negative comments represent $22.0 \%(\mathrm{~N}=313)$ of the comments on characters. 
Messages about actresses or actors $(9.5 \% ; \mathrm{N}=748)$ similarly include a greater number of positive evaluations $(63.4 \% ; \mathrm{N}=474)$ than negative $(7.7 \% ; \mathrm{N}=58)$ or neutral $(31.5 \%$; $\mathrm{N}=236)$. Twitter is the first platform of choice $(37.1 \% ; \mathrm{N}=168)$ due in part to the greater number of feeds from the actors and actresses on this social network, followed by Facebook $(33.7 \% ; \mathrm{N}=153)$ and forums $(29.1 \% ; \mathrm{N}=132)$. As with positive comments about the characters, there are more comments relating to actors than actresses, although only 33 of the 158 of this group's comments alluded to a physical aspect of the performers. Very few of the messages are negative $(7.7 \% ; \mathrm{N}=58)$.

\section{Community}

Of the comments $44.6 \%(\mathrm{~N}=2,524)$ explicitly, figuratively or implicitly express a feeling of belonging to a community of fans. The explicit manifestation $(12.1 \%$; $=948)$ predominates among regular female forum users and is mainly associated with a common cause, such as preventing the cancellation of a programme or lamenting the exit of an actor or actress. Questions are used fairly frequently to figuratively appeal to the community $(12.4 \%$; $\mathrm{N}=972$ ), although these are often accompanied by attempts to mobilise the community:

April22 - 12/10/2012 - 20:58 - Will there be a second season?

Sign here if you want to tell A3 that we fans want more.

http://www.change.org/es/peticiones/antena-3-que-haya-una-segunda-temporada-de-laserie-tv imperium (Imperium, Antena 3, 2012) ${ }^{10}$

The "conversations" between users implicitly reveal the feeling of belonging to a community $(20.1 \%$; $=1,576)$ through comments very similar to those for the previous group, debates about the plausibility of the storylines, recalling the most moving moments and discussions about information on the series' future (spoilers, continuation or cancellation, etc.). Viewers who prefer "trash programmes", such as Sálvame (Save Me, Tele5) or Gran Hermano (Big Brother, Tele5), to series that recall the history of Spain are also criticised:

Emylola - 02/04/2012 - 21:26 - How embarrassing

How embarrassing to see that in this country there are still people who are more in interested trash programmes such as "save me" or "big brother" (SO CULTURAL, FOR CRYING OUT LOUD) than cultural issues such as Toledo, to see Risto and KikO, which also show us loads of culture. What a country - I feel so depressed for being the way we are, IT'S NO WONDER WE DO SO POORLY (Toledo, cruce de destinos, Antena3, 2012 $\left.{ }^{11}\right)$. 
Of the comments analysed $10.5 \%(\mathrm{~N}=825)$ are pragmatic ${ }^{12}$ in nature. In other words, they aim to promote or incentivize action. Some of these comments therefore coincide with the messages inciting the mobilization described in the previous section (to prevent the cancellation of a series or to pressurize the broadcaster to show another season). Generally, they are associated with a positive appraisal of the plots and characters, although it is usual for these types of messages to reveal viewers' dissatisfaction at a series' sudden ending or the unexpected deviation away from a particular storyline that female users follow with special interest. A decrease in audience figures prompts some female users to predict the series' cancellation by the broadcaster, leading them to call for mobilisation and even suggesting possible solutions:

Lara903 - 29/10/2012 - 12:35

Something has to be done with isabel because if not they're going to take it off the air I think there are lots of options

- change the day

- include more advertisements

- make the series longer as "la voz" [the voice] and "el tiempo entre costura" [the time between seams] finish about 01:00 and Isabel at 23:45

- Take it off the internet because many people watch it on the web...(Isabel, La1, 2012$\left.2014^{13}\right)$.

The nature of the pragmatic comments varies according to the sites where they are posted. Thus, forums are usually more reflective and conversational, which doubtlessly attracts a more committed audience; spontaneous outpourings predominate on Facebook, while Twitter messages are more demanding and direct.

Comments congratulating the technical team, actors/actresses or the broadcaster $(3.9 \% ; \mathrm{N}=307)$ and both diegetic and non-diegetic complaints $(6.1 \% ; \mathrm{N}=477)$ include two groups of comments that are very similar to the previous ones except that they do not petition for mobilization. A programme's cancellation due to low audience figures, inconsistences in the storylines of some of the longer running series or the lack of historic rigour in programmes set in the past are the usual subjects of the most recurrent complaints, as is the inclusion of too many commercials. Some female viewers criticize the inadequate treatment of certain sensitive issues such as, for example, the repeated use of rape as a narrative motif:

Hortensia - 20/04/2013 - 09:58 
DON'T LET the rape of Soledad by her father happen. DON'T LET Pepa's own lover kill her and throw her body down the embankment. DON'T LET that quack kill Pepa. They rape Mariana and then she ends up is jail DON'T LET THAT HAPPEN, and now MARIA, night after night after her childhood has been a nightmare because of child rape. I ask myself whether there is anything inside the heads of the scriptwriters that doesn't involve RAPE day after day. This series makes me sick. (Tierra de lobos, Tele5, 2010$\left.2014^{14}\right)$.

\section{Extimacy}

The psychoanalyst Jacques Lacan coined the term extimacy to express the conflict between a subject's interior and exterior ${ }^{15}$. The concept, successively reworked by another French psychoanalyst, Serge Tisseron (2003), to designate the exteriority of the inner self, is very useful in defining the display of intimacy that occurs in forums and social networks (Arfucb, 2005), which is another manifestation of the feeling of belonging to a community of fans.

Thirty two percent $(\mathrm{N}=2,497)$ of the comments include references to viewing habits and the feelings and intimate experiences that female spectators have or relate to the fiction. These are self-reflective, with frequent descriptions of the small rituals surrounding reception and the emotions aroused by the programmes (Carolina Moreno Garcia: "I can't believe it's ending...... so sad, what am i going to watch at dinnertime for the rest of my life, what a shame, nooooooooooooo", Arrayán, CanalSur, 2001-2013 ${ }^{16}$ ). Of this group, 43.3\% $(\mathrm{N}=1,081)$ of comments refer to the intimacy of female users, who reveal both the various ways of watching (television or second screens) and their watching habits (juggling them with daily routines) or the social nature of reception (watching in the company of others; in solitary, commenting on the programme online with other viewers, etc.). Some female viewers mention their age or where they are from (Laura: 'I'm 13 years old and am from Cartagena", Frágiles, Tele5, 2012-2013). In contrast, 21.4\% (N=1,681) of the messages in the sample include references to the feelings aroused by the programmes:

Dolores Garcia Vazquez - 12/01/2013 - 16:30

[...] from the beginning this series has brought back many memories as my dad was in the war and he told me things like how they lived hidden in the sierras in Andalusia for being Reds if not they would have killed them as they hunted to eat, like rafalin and el chato [characters], how they swept away their footprints so they couldn't find them, how they went into town at night to look at their sleeping kids etc... wish they would make 
another series as real as this one. Thanks to all who made it. Well done all of you (Bandolera, Antena3, 2011-2013 ${ }^{17}$ ).

Emphasizing messages through the use of emoticons is a practice employed in $8.8 \%$ $(\mathrm{N}=692)$ of the comments analyzed in an attempt to symbolize both the feelings experienced and the relationship with the group. Twitter is the social network that includes the greatest number of such comments $(53.2 \% ; \mathrm{N}=368)$, presumably due to the limit on characters. Forums occupy second place $(31.0 \% ; \mathrm{N}=214)$, followed by Facebook $(15.8 \% ; \mathrm{N}=110)$. Messages that include emoticons are closer to colloquial language and young people's language, with the emoticons generally being located at the end of comments. Broadly speaking, messages that include emoticons can be divided into five groups. The first group is comments that celebrate the series' continuity into a new season. The second group thanks the contributions of the various members of the community. The third group of emoticons includes information about the comments' authors. The fourth group highlights the role of the series in structuring the female viewers' daily lives. Finally, the fifth and last group of messages fulfil a merely phatic function, emphasising the message. Most emoticons included in the messages express positive emotions.

\section{Discussion}

The messages analyzed here reveal that, in contrast to cult fandom, the participation of active posters and lurkers (Edelmann, 2013) in forums and social networks dedicated to Spanish television fiction rarely point to the construction of cultural or political identities (Russell et al., 2003). Rather, users attempt to connect the narrated storylines with their own lives (Bermejo et al., 2011). The reasons for their participation suggest the need to express themselves in terms of their feelings, with self-reflective comments about their intimate experiences that are emphasised through the use of colloquial language and emoticons.

In line with other online communities, we can confirm that the content of the messages reveals both the existence of emotional ties with the programmes and feelings of complicity between the members of the communities, who promote mobilisation mainly to call for a series' continuation or to prevent its cancellation (Stavros et al., 2014). In contrast, extremely negative criticisms or any desire for revenge typical of anti-fans rarely appear (Gray, 2005), which is another result that is compatible with the characteristics that, according to Bishop (2007), define online communities. 
This study does not allow us to infer that female-signed comments attempt to assert gender identity (Carstensen, 2009), although they criticize the repeated use of sexual violence against women in the narratives (Ferreday, 2015) and favour female characters with strong personalities. Neither is there any evidence for differences with regard to comments on programmes broadcast in Catalan, Basque or Galician. In general terms, it can be stated that this type of participation does not influence either identity construction or its maintenance (Sandvoss, 2011). Rather, it is an extension of an offline identity to the internet with no apparent conflicts (Dirksen et al., 2010) nor any particular evidence of the narcissism that characterises personal websites (Carpenter, 2012). Unlike cult fans, female fans of Spanish fiction do not express any need to demonstrate their expertise of the series beyond pointing out certain errors in the storylines such as the lack of historic rigour (Hills, 2015).

On the whole, it can be stated that what characterizes the communities of fans analyzed here is not so much their passion for the genre, nor their wish to demonstrate a good knowledge of a particular series, but female viewers' affinity with and closeness to the storylines.

The fragmentation of the interactions suggests the primacy of the "phatic" nature of the feedback (Jakobson, 1960), which is generally a result of the spontaneity of their participation (Evans, 2011) over the strengthening of "friendships" created around the programmes. The comments also demonstrate that the female viewers share their viewing habits and the various ways they watch series, which is a clear indication of the "extended sociability" of online communities (Bailliencourt et al., 2011), which in this case allows them to strengthen the sense of belonging to a group. In all, the fragmentation of the interactions and the lack of leaders who preside over debates reveal the configuration of a non-hierarchical online community with no specific dominant groups, something that facilitates the integration of female spectators and encourages female lurkers or less active fans to overcome their reservations and fears regarding participation (Sun et. al., 2014).

In relation to the type of social network female viewers use, this study confirms the results of other investigations that conclude that Facebook and Twitter do not favour deep interactivity (Bury, 2016). On the contrary, forums facilitate further discussion of comments and the inclusion of external sources, which increases knowledge of the subject and reinforces the construction of a collective intelligence (Jenkins, 2006). In short, comments in the forums appear to be more thoughtful, conversational and neutral, while Facebook seems to favour spontaneous outpourings, with messages written in real time and coinciding with the broadcast of the series. 
This study positively answers the two questions proposed. In relation to the first, the communities analyzed relate to the group in a notably different manner to how cult fans relate to each other. Despite the lack of expert knowledge or any great affinity toward other members, these communities reveal clear feelings of affection towards the shows they watch, and a significant degree of identification with the rest of the group based on self-reflection, the intersection between the storylines and their daily lives, and the manifestation of intimacy. A further distinguishing element is the absence of leaders or dominant groups; the relationships between members tend to be, therefore, more horizontal in nature. In short, a very popular way of relating even among the series' more mature female spectators, in a friendly setting that allows them to share emotions without generating conflicts. In this sense, the study shows the necessity for future research to explore the hypothesis that relations amongst women who comment on mainstream cultural products are more egalitarian than those that take place on other online communities, such as those composed by men or dedicated to more elitist cultural products.

Regarding question 2, it is worth pointing out that the participation of female viewers revolves mainly around the stories narrated, the identification with their daily lives, and the need to share their own personal experiences with the rest of the community. No demands for cultural, gender or political identities were in evidence. This absence of political demands is also related to the differences between cult fandom and the mainstream fandom. In this regard, the study shows that one of the defining characteristics of the fandom analyzed is the need to be part of a community where users can express themselves in a more intimate and spontaneous way, avoiding the need to show a great degree of expertise or intellectual knowledge.

The analysis of spontaneous comments about television fiction posted on the internet represents a novel area of investigation that is still in an early phase, particularly in Spain. Nevertheless, the tremendous impact of American TV fiction both in Spanish viewers and producers, allow us to assume that the results of American research on the subject can be extrapolated to the European Western European context. The research reveals that these types of communities, with their own characteristics, are important groups that differ markedly from cult fandoms. This area is particularly prolific and, considering the weight of the female audience and the influence of television -especially television fiction -in the social progress of women (Howard \& Katz, 2013), should be analyzed in greater detail. The integration of the methodology used here with other ethnographical approaches (interviews, surveys, 
participant observation in forums and social networks, etc.) would allow knowledge of these abundant, yet little-explored, groups to be broadened.

\section{Acknowledgements}

This part of the research was developed by the authors of the article and the following researchers and contributors: Beatriz Gómez, Mariluz Sánchez, Belén Granda, Tatiana Hidalgo, Paola Cabrera (researchers); Marc Bellmunt, Germán Muñoz, Lucía Trabajo, Estitxu Garai, Amaia Neracan, Elsa Soro, Karina Tiznado, Carlos Toural (contributors). Funding This article is part of a larger investigation project entitled "Social Construction of Women in the television fiction and web 2.0: Stereotypes, reception and feedback" [grant number FEM2012- 33411], funded by the Ministerio de Economia y Competitividad (Government of Spain).

\section{Notes on contributors}

Dr. Charo Lacalle is full professor and head of the Department of Communication and Journalism Studies at the Autonomous University of Barcelona. Her research focuses on TV, internet, and identity construction. She coordinates the Observatory of Spanish TV Fiction and New Technologies (OFENT) and the Spanish team of the Ibero-American Observatory of TV Fiction (OBITEL).

Dr. Núria Simelio is a senior lecturer in the Department of Journalism Studies at the Autonomous University of Barcelona. She is a member of the Laboratory for Journalism and Communication Science for the Diverse Citizenship at UAB. Her research focuses on feminist media studies and the study of new forms of content production and social practices.

\section{References}

Arfuch, L. (2005). Introducción. In Arfuch, L. (Ed.) Pensar este tiempo. Espacios, afectos, pertenencias (pp. 1-6). Buenos Aires: Paidós.

Bailliencourt, T., De Beauvisage, T., Granjon, F. \& Zbigniew, S (2011). Extended sociability and relational capital management: interweaving ICTs and social relations. In Ling, J. \& Campbell S.W (Eds.) Mobile communication: bringing us together or tearing us apart? The mobile. (pp. 151-179). Washington: Transaction Publishers. 
Baym, N.K. (2000). Tune in, log on: Soaps, fandom, and online community. Thousand Oaks, London, New Delhi: Sage Publications.

Bermejo, J., De Frutos, B. \& Couderchon, P. (2011). Los valores del consumo de ficción audiovisual en la migración digital hacia diferentes pantallas. Trípodos, Extra, 209218.

Bielby, D. \& Harrington, C. (1995). Soap fans: Pursuing pleasure and making meaning in everyday life. Filadelfia: Temple University Press.

Bishop, J. (2007). Increasing participation in online communities: A framework for humancomputer interaction. Computers in Human Behavior, 23(4), 1881-1893. doi:10.1016/j.chb.2005.11.004

Black, R.W. (2008). Adolescents and online fan fiction. New York: Peter Lang Publishing.

Bird, E.S. (2011). Are we all produsers now? Cultural Studies, 25(4-5), 502-516. doi: $10.1080 / 09502386.2011 .600532$

Booth, P. (2008). Rereading fandom: MySpace character personas and narrative identification. Critical Studies in Media Communication, 25(5), 514-536. doi:10.1080/15295030802468073.

Brennan, J. (2014). "Fandom is full of pearl clutching old ladies": Nonnies in the online slash closet. International Journal of Cultural Studies, 17(4), 363-380. doi: $10.1177 / 1367877913496200$

Brooker, P. \& Brooker, W. (1996). Pulpmodernism: Tarantino's affirmative action. In: Cartmell, D., Kaye, H., Hunter, I.Q. \& Whelelan, I. (Eds.) Pulping fictions: Consuming culture across the literature/media divide (pp. 89-100). London: Pluto.

Bruns, A. (2006). Towards produsage: Futures for user-led content production. In: Sudweeks, F., Hrachovec, H. \& Ess, Ch. (Edss) Proceedings Cultural Attitudes towards Communication and Technology (pp. 275-284). Tartu: Estonia.

Bury, R. (2005). Cyberspaces of their own: Female fandoms online. New York: Peter Lang.

Bury, R. (2016). Technology, fandom and community in the second media age. Convergence: The International Journal of Research into New Media Technologies, 24, 1-16. doi: 10.1177/1354856516648084

Calka, M. (2015). Polymediation: The relationship between self and media. In: Herbig, A., Herrmann A. F., \& Tyma A.W. Beyond new media: Discourse and critique in a polymediated age. (pp.15-30). Maryland: Lexington Books. 
Carpenter, C.J. (2012). Narcissism on Facebook: Self-promotional and anti-social behavior. Personality and Individual Differences, 52(4), 482-486. doi: dx.doi.org/10.1016/j.paid.2011.11.011

Carstensen, T. (2009). Gender trouble in web 2.0. Gender relations in social network sites, wikis and weblogs. International Journal of Gender, Science and Technology, 1(1), 105-127. Retrieved from: http://genderandset.open.ac.uk

Cherry, B. (2002). Screaming for release: Femininity and horror film fandom in Britain. In Chibnall, S. \& Petley, J. (Eds) British Horror Cinema. (pp. 42-57). London: Routledge.

Costello, V. \& Moore, B. (2007). Cultural kutlaws. An examination of audience activity and Online Television Fandom. Television \& New Media, 8(2), 124-143. doi: $10.1177 / 1527476406299112$

De Certeau, M. (1990). L'Invention du quotidien: Les Arts de faire (I). Paris: Gallimard. Dirksen, V., Huizing, A. \& Smit, B. (2010). "Piling on layers of understanding": The use of connective ethnography for the study of (online) work practices. New Media and Society, 12(7), 1045-1063. doi: 10.1177/1461444809341437

Duffett, M. (2013). Understanding fandom: An introduction to the study of media fan Culture. New York: Bloomsbury Academic.

Edelmann, N. (2013). Reviweing the definitions of lurkers and some implications for online research. Cyberpsychology, Behavior and Social Networking, 16(9), 645-649. doi:

$10.1089 /$ cyber.2012.0362

Evans, E. (2011). Transmedia relevision. Audiences, new nedia and daily life. New York/Oxon: Routledge.

Gray, J. (2005). Antifandom and the moral text. Television without pity and textual dislike. American Behavioral Scientist, 48(7): 840-858. doi: 10.1177/0002764204273171

Gray, J., Cornel, S. \& Harrington, C.L. (2007). Fandom: Identities and communities in a mediated world. New York: New York University Press.

Harrington, C.L. \& Bielby, D.D. (2010). A life course perspective on fandom. International Journal of Cultural Studies, 13(5), 429-450. doi: 10.1177/1367877910372702

Harrington, C. L., \& Bielby, D. D., (2011). Life course transitions and the future of fandom. International Journal of Cultural Studies, 14(6), 567-590. . doi: $10.1177 / 1367877911419158$

Hellekson, K. (2009). A fannish field of value: Online fan gift culture. Cinema Journal, 48(4), 113-118. doi:10.1353/cj.0.0140 
Herbig, A., Herrmann, A. F. \& Tyma, A. (2015). Introduction: The beginnings: \#WeNeedaWord. In A. Herbig, A. F. Herrmann, \& A. W. Tyma (Eds.), Beyond new media: Discourse and critique in a polymediated age (pp. ix-xxiv). Lanham, MD: Lexington Books.

Hills, M. (2002). Fan Cultures. London: Routledge.

Hills, M. (2010). When television doesn't overflow "beyond the Box": The Invisibility of "momentary" fandom. Critical Studies in Television: The International Journal of Television Studies, 5(1), 97-110. doi: 10.7227/CST.5.1.10

Hills, M. (2015). The expertise of digital fandom as a "community of practice": Exploring the narrative universe of Doctor Who. Convergence: The International Journal of Research into New Media Technologies, 21(3), 360-374. doi: $10.1177 / 1354856515579844$

Howard-Williams, R. \& Katz, E. (2013). Did television empower women? The introduction of television and the changing status of women in the 1950s. The Journal of Popular Television, 1(1), 7-24. doi: 10.1386/jptv.1.1.7_1

Jakobson, R. (1960). Linguistics and poetics. In T. Sebeok (Ed.), Style in Language (pp. 350377). Cambridge, MA: M.I.T. Press.

Jenkins, H. (1992). Textual poachers: Television fans \& participatory culture. New York: Routledge

Jenkins, H. (2006). Convergence culture. Where old and new media collide, New York and London: New York University Press.

Jenkins, H. (2007). Afterword: The future of fandom. In Gray, J., Sandvoss, C., \& Harrington, C. L. (Eds.), Fandom: Identities and communities in a mediated world (pp. 357-364). New York: New York University Press.

Larsen, P. (2010). The grey area. A rough guide. Television fans, internet forums, and the cultural public sphere. In Gripsrud, J. (Ed.), Relocating television. Television in the digital context (pp. 157-168). New York: Routledge.

Ling, R., \& Thrane K (2002). I don't watch TV to like learn anything: The leisure use of TV and the internet. First Monday, 7 (1). Retrieved from http://firstmonday.org/issues/issue7 1/ling/index.html.

Pearson, R. (2010). Fandom in the digital era. Popular Communication 8(1), 84-95. doi: $10.1080 / 15405700903502346$

Peirce, C. S. (1997[1903]). Pragmatism as a principle and method of right thinking: the 1903 harvard cectures on pragmatism by Charles Sanders Peirce. Edited, introduced, and 
with a commentary by Patricia Ann Turrisi. Albany, NY: State University of New York Press.

Ridings, C. M. \& Gefen, D. (2004). Virtual community attraction: Why people hang out online. Journal of Computed-Mediated Communication, 10 (1). DOI: 10.1111/j.10836101.2004.tb00229.x

Salazar Rodríguez, M. (2015). Las llamaban histéricas: Movimiento fan desde una perspectiva de género [They were called hysterical: Fan movement from a gender perspective]. Tempora. Revista de Sociología de la Educación, 18, 75-94.

Sandvoss, C. (2013). Toward an understanding of political enthusiasm as media fandom: Blogging, fan productivity and affect in American politics. Participations, 10(1), 252296. Retrieved from http://www.participations.org/Volume $\% 2010 /$ Issue $\% 201 / 12 \mathrm{a} \% 20$ Sandvoss $\% 2010 \% 2$ 01.pdf.

Sandvoss, C. (2011). Fans online: Affective media consumption and production in the age of convergence. In Christensen, M., Jansson, A., \& Christensen, C. (Eds.), Online territories (pp. 49-74). Peter Lang: New York.

Spottswood, E. L., Walther J. B., Holmstrom, A. J., Ellison, N. B. (2013). Person-centered emotional support and gender attributions in computer-mediated communication. Human Communication Research, 39(3), 295-316. doi:

http://dx.doi.org/10.1111/hcre.12006

Stavros, C., Meng, M., Westberg, K., Farrelly, F. (2014). Understanding fan motivation for interacting on social media. Sport Management Review, 17 (4), 455-469. doi:10.1016/j.smr.2013.11.004

Sun, N., Rau, P. P.-L., Ma, L. (2014). Understanding lurkers in online communities: A Literature Review. Computers in Human Behavior, 38, 110-117. doi : 10.1016/j.chb.2014.05.022

Tisseron, S. (2003). Hitchcock m'a guéri [Hitchcock healed me]. París: Albin Michel. Williams, R. (2015). Post-object fandom: Television, identity and self-narrative. New York: Bloomsbury Academic.

Wilson, S. (2016). In the living oom: Second screens and TV audiences. Television \& New Media, 17 (2), 174-191. doi: 10.1177/1527476415593348

Wood, H., \& Taylor, L. (2007). Feeling sentimental about television and audiences. Cinema Journal, 47(3), 144-51. 
${ }^{1}$ Adjectives and participles present a morphological agreement in the three Latin languages spoken in Spain (Spanish, Catalan and Galician), while Basque language always uses a different word for distinguish masculine and feminine.

${ }^{2}$ The public television system in Spain consists of two state television channels (La1 and La2) and 26 autonomous channels. Channels in bilingual Autonomous Communities (Catalonia, the Basque Country, the Balearic Islands Community, Valencian Community, and Galicia) broadcast their domestic fiction programmes in their respective co-official local languages, with the exception of the Basque Country, which also has a channel in Spanish.

${ }^{3}$ The thematic complexity of a discursive unit lies in the inclusion of various variables and subvariables in a single message.

${ }^{4}$ Amar en tiempos revueltos is a soap opera set in the 1950s and is characterized by the number of questions of social interest it addresses.

${ }^{5}$ The remaining 82 positive comments make joint references to characters.

${ }^{6}$ Gran reserva is a drama relating the family saga of wine-producers in Rioja. Vicente, the head of the family, is manipulative and unscrupulous.

${ }^{7}$ Aida is a sitcom protagonised by various generations of a lower class, dysfunctional family. Luisma is an ex-drug addict characterized by his freakishness.

${ }^{8}$ Frágiles is a drama set in the clinic of a therapist who is more of a psychologist to his patients. Lola is a young girl with Asperger's syndrome.

${ }^{9}$ La que se avecina is a sitcom set in a neighbourhood community. Estela is an idle, selfish, narcissistic woman.

${ }^{10}$ Imperium (Antena3, 2012) is a drama set in the $2^{\text {nd }}$ century AD. Low audience figures resulted in its cancellation after six episodes, prompting angry protests from viewers.

${ }^{11}$ Toledo, cruce de destinos (Tele5, 2013) is an action adventure series set in its namesake city in the $18^{\text {th }}$ century that was cancelled at the end of its first season due to low audience figures.

${ }^{12} \mathrm{We}$ use this concept in its practical dimension of language, in accordance with the meaning defined the US semiotician Charles Sanders Peirce (1997[1903]), to define the involvement of broadcaster in an action through the simple act of saying it or when it attempts to provoke a determined practical effect.

${ }^{13}$ Isabel (La1, 2012-14) is a biopic of Isabel I of Castile, "The Catholic Queen".

${ }^{14}$ Tierra de lobos is a type of Spanish western set in $19^{\text {th }}$ century southern Spain.

${ }^{15}$ For more information about the Lacanian meaning of extimacy, see Miller (2010).

${ }^{16}$ Arrayán is a soap opera that relates the relationships of the staff and guests of a large hotel.

${ }^{17}$ Bandolera is a soap opera set in $19^{\text {th }}$ century Andalusia that relates the relationship of a young English aristocratic lady with a group of bandits who rob the rich to help the poor. 